\title{
THE RELATIVE SUSCEPTIBILITY OF CERTAIN OKRA VARIETIES AGAINST THE SPINY BOLLWORM EARIAS INSULANA (BOISD.) (LEPIDOPTERA: NOCTUIDAE)
}

\author{
AMRO, MOHAMED A. ${ }^{1}$, G. H. ABD EL-RAHIM ${ }^{2}$ AND Y. M. A. ABDEL-GALIL ${ }^{1}$ \\ 1. Plant Protection Research Institute, ARC, Dokki, Giza, Egypt \\ Email Address: (Moamro1953@yahoo.com) \\ 2. Horticulture Department, Faculty of Agriculture, El-Azhar University, Assiut. \\ Egypt
}

(Manuscript received 5 October 2011)

\begin{abstract}
Fourteen okra varieties were tested in Assiut governorate to estimate their fruit infestation degrees caused by the spiny bollworm Earias insulana (Boisd.) and to determine their susceptibility degrees against this insect pest. Irany, Red base and Balady 4 okra varieties recorded the highest infestation values with an average of $11.92 \%>10.40 \%>9.13 \%$, respectively. However, Oraby, Balady 5 and Balady 6 okra varieties recorded the lowest values with an average of $6.93 \%>6.79 \%>6.75 \%$, respectively, as an average of the two successive seasons of 2009 and 2010. The highest infestation was recorded during the last three weeks of August. Dependent on the mean numbers of (Bores + larvae), the tested varieties revealed different susceptibility degrees to the pest. Balady 5 and Balady 6 varieties harboured the lowest numbers and appeared as highly resistant (HR) varieties. The remaining varieties revealed different susceptibility degrees to the pest. Negative correlation was recorded between the numbers of hairs presented on fruit surface of both Balady 5 and Balady 6 varieties and the pest infestation. Therefore, okra varieties that showed some sort of resistance can be included among advanced breeding programs to select new varieties resistance to $E$. insulana.
\end{abstract}

\section{INTRODUCTION}

Assiut governorate cultivated more than 900 feddan of okra every year, however, the entire cultivated area in Egypt were 16665 feddan during 2008 season as reported by the Statistic's of Egyptian Ministry of Agriculture (MOA), (2008). Okra suffers from several foliage and fruit insect pests. The spiny bollworm, Earias insulana (Boisduval) (Lepidoptera: Noctuidae) is a serious pest of okra. It attacks growing points, but when fruiting bodies start to appear, it feeds mostly inside squares, flowers and fruits. One larva can damage several fruiting bodies during its life span. The economic injury level of Earias spp. on okra is recorded to be $5.3 \%$ damage (Krishnaiah et. al., 1978). Several authors reported the damage caused by Earias spp. to okra crop. For example, Srinivanan and Krishnakumar (1983) recorded 9.3\% infestation of Earias vittella, however, Dhawan and Sindhur (1984) 
observed maximum fruit damage of $67.7 \%$ and $25.04 \%$ to buds of okra by Earias spp.

Host plant resistance (HPR) is one of the most cost-effective and safe method belonging to Integrated Pest Management (IPM). Plants contain a large number of substances, which have their primary use as a mean of defense against insect pests. A resistant variety can provide a base on which to construct an integrated control system (Maxwell et. al., 1972, Gallum et. al., 1975) and may be most fruitful when used in connection with other methods of control. HPR seems to be a sustainable approach to pest management and varietal trials of different okra genotypes to their main insect pests. Scarce information on the varietal resistance of okra against Earias spp. were obtained. Therefore, the present investigation was under taken to measure the percent of infestation of the spiny bollworm E. insulana attacking certain okra varieties. Also, to determine the pest population fluctuations and consequently the relative susceptibility of the tested okra varieties against this insect pest.

\section{MATERIALS AND METHODS}

The present study determined the infestation percentage in addition to the population fluctuations and varietal resistance of certain okra varieties against Earias insulana Boisd. The work has been done at Al-Azhar experimental farm Al-Azhar University, Assiut governorate during 2009 and 2010 growing seasons. Seeds of the tested varieties were obtained from different sources as shown in Table 1.

Table 1. Name, source and yield of the tested okra varieties.

\begin{tabular}{|c|c|c|c|c|c|c|c|}
\hline \multicolumn{4}{|c|}{ Okra varieties } & \multicolumn{4}{|c|}{ Okra varieties } \\
\hline \multirow{2}{*}{$\frac{\text { Name }}{1 \text { - Balady } 1}$} & Source & \multicolumn{2}{|c|}{ Yield kg/fed. } & \multirow{2}{*}{$\frac{\text { Name }}{\text { 8- Balady } 8}$} & \multirow{2}{*}{$\begin{array}{r}\text { Source } \\
\text { Tema-Sohag }\end{array}$} & \multicolumn{2}{|c|}{ Yield kg/fed. } \\
\hline & $\begin{array}{l}\text { Shaban El- } \\
\text { Korma, Cairo }\end{array}$ & 995.53 & I & & & 1799.62 & E \\
\hline 2- Balady 2 & Luxor & 1435.43 & G & 9- Irany & Tema-Sohag & 2318.53 & $C D$ \\
\hline 3- Balady 3 & Sohag & 841.13 & 了 & 10-Saudi & Om Doma-Sohag & 2890.98 & A \\
\hline 4- Balady 4 & $\begin{array}{l}\text { El-Barka } \\
\text { company, } \\
\text { Sohag }\end{array}$ & 884.42 & IJ & $\begin{array}{c}\text { 11- Sobaa El- } \\
\text { Set }\end{array}$ & Fayoum & 1250.53 & $\mathrm{H}$ \\
\hline 5- Balady 5 & Quena & 2371.80 & $\mathrm{C}$ & 12- Oraby & Tahta-Sohag & 2207.18 & $\mathrm{D}$ \\
\hline 6- Balady 6 & $\begin{array}{l}\text { Sahel-Sleem, } \\
\text { Assiut }\end{array}$ & $2588 / 88$ & B & 13- Red Base & $\begin{array}{l}\text { Al-Mohandes } \\
\text { Company, Assiut }\end{array}$ & 1817.20 & $E$ \\
\hline 7- Balady 7 & Aswan & 1160.83 & $\mathrm{H}$ & $\begin{array}{r}\text { 14- Smooth } \\
\text { green }\end{array}$ & $\begin{array}{l}\text { Al-Mohandes } \\
\text { Company, Assiut }\end{array}$ & 1653.88 & $\mathrm{~F}$ \\
\hline
\end{tabular}

The sowing of the tested okra varieties was done in the first week of March in the two successive growing seasons, 2009 and 2010, in a randomized complete block 
design. Replicates were $3.00 \times 3.50$ meter/each variety. Conventional agricultural practices were performed and insecticidal treatments were completely prevented.

\section{1- Percent infestation of Earias insulana on the tested okra varieties:}

Percent infestation of $E$. insulana that attacking the tested okra varieties was determined by picking up 10 green okra fruits from 3 replicates and transferred to the laboratory in muslin bags. Percent infestation was measured by visual observations. Because the observed bores expressed about the larval emergence, numbers of bores expressed about the infestation caused by the pest. The observed pest infestation were counted weekly from the first week of July, till harvest.

\section{2- Population fluctuations and relative susceptibility of okra varieties against $E$. insulana:}

The same 10 okra fruits were dissected after transferred to the laboratory. Numbers of $E$. insulana larvae were counted during the same period. Mean numbers of (Bores + larvae) were used to determine the population fluctuations and the relative susceptibility degree of the tested varieties as described by Chiang and Talekar (1980) equation. Relative susceptibility degree was dependent on the general mean number of the pest $(\overline{\mathrm{X}})$ and the standard deviation (SD). Varieties that had mean numbers more than $\bar{X}+2 S D$, were considered highly susceptible (HS), between $\bar{X}$ and $\bar{X}+2 S D$, susceptible (S), between $\bar{X}$ and $\bar{X}-1 S D$, low resistant $(L R)$, between $\bar{X}-1 S D$ and $\bar{X}-2 S D$, moderately resistant (MR) and less than $\bar{X}$ 2SD, were considered highly resistant (HR). Correlation coefficient between some okra physical and chemical characters and the pest infestation were calculated. Data were statistically analyzed by using F-test, means were compared according to Duncan's multiple range test as described by Steel and Torrie (1982).

\section{RESULTS AND DISCUSSION}

\section{Percent infestation of Earias insulana on the tested okra varieties:}

Data presented in Table (2) expressed about the infestation percentage of $E$. insulana on okra fruits in Assiut region during 2009 growing season. The obtained results revealed highly significant variations between the tested okra varieties and/or between the inspection dates. The highest percent infestation was recorded on the Irany okra variety with an average of $12.50 \%$. However, the lowest one was recorded on Balady 5 variety with an average of $6.92 \%$. The remaining varieties showed differential values of infestation.

Concerning the inspection dates, percent infestation was increased gradually as the plant aged. The infestation percentages during August 3, 10, 17 and 24 recoded 
$6.33 \%, 9.44 \%, 12.17 \%$ and $17.62 \%$, respectively. So, there is no dough that the spiny bollworm populations increased gradually with the developmental stage of okra plants.

The obtained results during the second year of study 2010, in Table (3) showed that the highest percent infestation was recorded on the Red base okra variety with an average of $12.04 \%$. However, the lowest one's was recorded on Balady 1, Balady 2 and Balady 5 varieties with an average of $6.67 \%, 6.92 \%$ and $6.67 \%$, respectively. Inspection dates showed similar trends of the percent infestation that recorded during the first year of study. The highest infestation percentages were recorded during the last three weeks of August with an average of $13.57 \%, 8.48 \%$ and $17.02 \%$, respectively.

Mean infestation percentage, during the 2 successive growing seasons, 2009 and 2010 illustrated in figure (1). The highest infestation percentages were recorded on Irany, Red base and Balady 4 okra varieties, with an average of $11.92 \%, 10.40 \%$, and $9.13 \%$, respectively. However, the lowest one's were recorded on Oraby, Balady 5 and Balady 6 okra varieties with an average of $6.93 \%, 6.79 \%$ and $6.75 \%$, respectively as an average of the two seasons. It is of importance to notice that the last three varieties, recorded high yield income (Table 1 ).

In similar results Younis and Ibrahim (2010) recorded three peaks of infestation caused by $E$. insulana on cotton in El-Minia region, Middle Egypt, during the last week of July, the last week of August and the second week of September, with an average of $34 \%, 36 \%$ and $33 \%$, respectively. Concerning the infestation periods, Abro et. al. (2004) revealed that Earias spp. infestation appeared about 45 days after sowing of the crop. Also, they recorded high infestation of the pest (18.45\%) on okra growing as mono crop, compared with okra/cotton mixed plantations. In this respect, Kumar and Urs (1988) studied the seasonal incidence of $E$. vittella on okra and found that the pest started its infestation on shoots and fruits. The infestation of fruits varied from 8.4 to $73.2 \%$ throughout the study period. However, Singh and Brar (1994) reported that the loss in the yield due to Earias spp. infestation varied from 32.06 to $40.84 \%$. So, the extent of loss to okra due to infestation of Earias spp., has been reported by various workers in the range of 20 to 51\% (Abhishek-Shukla et. al., 1997).

\section{2- Population fluctuations and relative susceptibility of okra varieties against $E$. insulana:}

Mean numbers of (bores + larvae) expressed about the incidence and/or population fluctuations of the pest. So, data in Table (4) indicate the pest fluctuations during 2009 growing season. The obtained results revealed that the highest densities of the pest occurred on Sobaa-El-Set, Balady 7 and Irany varieties with an average of 
$1.46,1.45$ and 1.30 individuals/ten fruits, respectively. On the other hand, the lowest densities appeared on Balady 4, Balady 5, Balady 6, Balady 8 and Saudi varieties with less than one individual/ ten fruits. Concerning the periods of the pest incidence, the highest populations were occurred during the last three weeks of August with an average of $1.24,1.55$ and 2.43 individuals/ten fruits, respectively. During 2010 growing season the obtained results in Table (5) revealed that the highest density of the pest occurred on Sobaa El-Set variety with an average of 1.46 individuals/ten fruits, while the lowest density occurred on Balady 3 variety with an average of 0.46 individuals/ten fruits. Inspection dates revealed the similar trend to the first year of study.

Data presented in Table (6) expressed about the mean numbers of (Bores + larvae) occupied during the entire study period. The obtained results showed that the highest density of the pest was occurred on Sobaa-El-Set variety with an average of 1.46 individuals/ten fruits, however, the lowest densities was occurred on Balady 3, Balady 4 and Balady 5 varieties with an average of $0.86,1.01$ and 0.88 individuals/ten fruits, respectively. Highly significant differences were obtained between the tested varieties.

Concerning the relative susceptibility, the same results in Table (6) which were dependent on the mean numbers of (Bores + larvae) can express about the resistance status of the tested okra varieties. Data revealed highly significant differences among studied okra varieties. The tested varieties Balady 3, Balady 5 and Balady 6 harbored the lowest pest individuals and appeared as highly resistant (HR) varieties. However, Balady 7, Sobaa El-Set and Smooth green harbored the highest pest individuals and appeared as highly susceptibility (HS) varieties.The remaining okra varieties showed different susceptibility categories. Balady 2, Irany and Red Base appeared as low resistant (LR) varieties, while, Balady 8, Saudi and Oraby appeared as Moderately Resistant (MR) varieties. So, the tested resistant varieties can interact synergistically with biological, chemical and cultural control methods to reduce spread of the pest.

Scarce information was obtained on the varietal resistance of okra against Earias spp. Few investigators concerned with this approach, eg. Madave and Dunbre, 1985, Vyas and Patel, 1990, Kumbher et. al., 1991, Patel et. al., 1996 and Memon et. al., 2004. In this respect, Madave and Dunbre (1985) determine the resistance status of 14 okra varieties against E. vittella. They recorded 4 tolerant and 2 resistant okra varieties against the pest. Also, Memon et. al. (2004) tested the resistance status of 6 okra varieties against Earias spp. They dependent on the maximum and the minimum percent infestation to determine the most and the least susceptible varieties. 
In respect to the correlation coefficient between the pest infestation and the tested plant characters, no significant positive and/or negative correlation was recorded. However, data in Table (7) indicated that numbers of hairs presented on Balady 5 and Balady 6 fruit surface had negative correlation with the pest infestation. It is of importance to note that the aforementioned varieties were recorded as highly resistant (HR) varieties. The remaining chemical characters had differential correlation values with the pest infestation. In this approach Kumbher et. al. (1991) found okra resistant to $E$. vitella correlated with increased fruit hair density. Therefore varieties that showed some sort of resistance can be included among advanced breeding programs to select new varieties resistant to $E$. insulana.

\section{REFERENCES}

1. Abhishek-Shukla, R. K. Agrewal, S. C. Pathak and A. Shukla. 1997. Seasonal incidence of okra shoot and fruit borer, Earias vittella (Fab.) and effect of temperature on its infestation level. Advances in Pl. Sci., 10: 169-172.

2. Abro, G. H., A.J. Memon, T. S. Syed and A. A. Shaikh. 2004. Infestation of Earias spp. on cotton and okra grown as mono and mix crops. Pakistan J. Biol. Sci., 7 (6): 937-942.

3. Chiang, H. S. and N. S. Talekar. 1980. Identification of sources of resistance to the bean fly and two other Agromyzid flies on soybean and mungbean. J. Econ. Entomol., 73 (2): 197-199.

4. Dhawan, A.K. and A.S. Sindhu. 1984. Incidence of relative abundance of different species of spiny bollworms on okra at Ludhiana, Punjab. J. Res. Punjab Agric. Univ., 21: 533-542.

5. Gallum, R. L., K. J. Starks and W. D. Guthrine. 1975. Plant resistance to insects attacking cereals. Annu. Rev. Entomol., 20: 337.

6. Krishnaiah, K., J. N. Mohan and P. R. Ramachander. 1978. Economic injury level and equential sampling plan for okra fruit borer, Earias vittella Fab. Bull. Entomol., Layola College, 19: 114-118.

7. Kumar, K. K. and K. C. D. Urs 1988. Population fluctuation of Earias vitella (Fab.) on okra in relation to abiotic factors. Indian, J. Pl. Protection, 16: 137-142.

8. Kumbher, T. T., A. Dumbre and A. S. Kokate. 1991. Studies on the varietal resistance in okra, Abelmoschas esculentus L. (Moench) to shoot and fruit borer, Earias spp. Moharashtra J. Hort., 5: 78-82.

9. Madav, R. P. and R. B. Dunbre. 1985. Reaction of okra varieties to shoot and fruit borer. J. Maharashtra Agric. Univ., 10: 276-277. 
10. Maxwell, F. G., N. J. Johine and W. L. Parrott. 1972. Resistance of plant to insects. Adv. Agron., 24: 187-265.

11. Memon, A. J., G. H. Abro and T. S. Syed. 2004. Varietal resistance of okra against Earias spp. J. Entomol., 1 (1): 1-5.

12. Patel, Y. B., B. D. Biradar, R. H. Hosmani and B. B. Madalageri. 1996. Evaluation of okra genotypes against pod borer, Earias spp. under field conditions in kharif season. Karanataka J. Agric. Sci., 9: 542-544.

13. Singh, G. and K. S. Brar. 1994. Effect of dates of sowing on the incidence of Amrasea biguttula (Ishida) and Earias spp. on okra. Indian J. Ecol., 21: 140-144.

14. Srinivasan, K. and U. K. Krishnakumar. 1983. Studies on the extent of loss and economics of pest management in okra. Trop. Pest Manag., 29: 363-370.

15. Statistics of the Egyptian Ministry of Agriculture and Land Reclamation, 2008. In (Arabic).

16. Steel, R. G. D. and J. H. Torrie. 1982. Principles and Procedures of Statistics. A biometrical approach, McGraw-Hill Book Co.

17. Younis, A. M. and Sanaa A. Ibrahim. 2010. Population fluctuations of the spiny bollworm, Earias insulana (Boisduval), Pink bollworm, Pectinophora gossypiella (Saunders) and their associated predators. Beltwide cotton conferences, New Orleans, Louisiana, Jan. 4-7, 2010.

18. Vyas, S. H. and J. R. Patel. 1990. Relative susceptibility of some lady's finger cultivars to Earias vittella (Fabricius). Indian J. PI. Protection, 18: 115-118. 
Table 2. Percent age infestation of Earias insulana on Okra fruits ${ }^{\circledR}$ in Assiut region during 2009 growing season.

\begin{tabular}{|c|c|c|c|c|c|c|c|c|c|c|c|c|c|c|c|}
\hline \multirow{2}{*}{$\begin{array}{c}\text { Inspection } \\
\text { date }\end{array}$} & \multicolumn{14}{|c|}{ Okra varieties } & \multirow[b]{2}{*}{ Mean } \\
\hline & $\begin{array}{c}\text { Balady } \\
1 \\
\end{array}$ & $\begin{array}{c}\text { Balady } \\
2 \\
\end{array}$ & $\begin{array}{c}\text { Balady } \\
3 \\
\end{array}$ & $\begin{array}{c}\text { Balady } \\
4 \\
\end{array}$ & $\begin{array}{c}\text { Balady } \\
5 \\
\end{array}$ & $\begin{array}{c}\text { Balady } \\
6 \\
\end{array}$ & $\begin{array}{c}\text { Balady } \\
7 \\
\end{array}$ & $\begin{array}{c}\text { Balady } \\
8 \\
\end{array}$ & Irany & Saudi & $\begin{array}{l}\text { Sobaa } \\
\text { El-Set }\end{array}$ & Oraby & $\begin{array}{l}\text { Red } \\
\text { base }\end{array}$ & $\begin{array}{c}\text { Smooth } \\
\text { green }\end{array}$ & \\
\hline July 6 & 3.33 & 5.00 & 6.67 & 3.33 & 10.00 & 3.33 & 13.33 & 3.33 & 6.67 & 13.00 & 10.00 & 3.33 & 6.67 & 13.33 & $7.24 \mathrm{D}$ \\
\hline July 13 & 3.33 & 3.33 & 13.33 & 3.33 & 2.00 & 3.33 & 10.00 & 2.00 & 6.67 & 2.00 & 3.33 & 2.00 & 6.67 & 3.33 & $4.62 \mathrm{~F}$ \\
\hline July 20 & 6.67 & 3.33 & 3.00 & 2.00 & 3.33 & 3.33 & 3.33 & 5.00 & 10.00 & 6.00 & 13.33 & 3.33 & 6.67 & 6.67 & $5.43 \mathrm{~F}$ \\
\hline July 27 & 13.33 & 10.00 & 6.67 & 6.67 & 6.67 & 6.67 & 17.33 & 10.00 & 13.33 & 6.67 & 13.33 & 6.67 & 6.67 & 2.00 & $9.00 \mathrm{C}$ \\
\hline Aug. 3 & 13.33 & 2.00 & 10.00 & 3.33 & 3.33 & 3.33 & 3.33 & 3.33 & 6.67 & 6.67 & 6.67 & 10.00 & 6.67 & 10.00 & $6.33 \mathrm{E}$ \\
\hline Aug. 10 & 6.67 & 10.00 & 20.00 & 6.67 & 10.00 & 10.00 & 6.67 & 6.67 & 20.00 & 6.67 & 6.67 & 2.00 & 10.00 & 10.00 & $9.44 \mathrm{C}$ \\
\hline Aug. 17 & 13.33 & 13.33 & 6.67 & 20.00 & 13.33 & 17.33 & 13.33 & 6.67 & 20.00 & 4.67 & 5.00 & 16.67 & 13.33 & 6.67 & $12.17 \mathrm{~B}$ \\
\hline Aug. 24 & 26.67 & 13.33 & 10.00 & 16.67 & 6.67 & 10.00 & 16.67 & 30.00 & 16.62 & 23.33 & 26.67 & 23.33 & 13.33 & 13.33 & $17.62 \mathrm{~A}$ \\
\hline \multirow[t]{2}{*}{ Mean } & 10.83 & 7.54 & 9.54 & 7.75 & 6.92 & 7.17 & 10.50 & 8.39 & 12.50 & 8.63 & 10.63 & 8.43 & 8.75 & 8.17 & \\
\hline & $B$ & EFG & $C D$ & EFG & G & FG & $\mathrm{BC}$ & DEF & A & $\mathrm{DE}$ & BC & DEF & DE & $\mathrm{EF}$ & \\
\hline
\end{tabular}

Means followed by the same letter are not significantly different at 0.05 level of probability by Duncan's multiple range test.

@Based on 10 green fruits /replicate. 
Table 3. Percent age infestation of Earias insulana on Okra fruits ${ }^{\circledR}$ in Assiut region during 2010 growing season.

\begin{tabular}{|c|c|c|c|c|c|c|c|c|c|c|c|c|c|c|c|}
\hline \multirow{2}{*}{$\begin{array}{c}\text { Inspection } \\
\text { date }\end{array}$} & \multicolumn{14}{|c|}{ Okra varieties } & \multirow[b]{2}{*}{ Mean } \\
\hline & $\begin{array}{c}\text { Balady } \\
1 \\
\end{array}$ & $\begin{array}{c}\text { Balady } \\
2\end{array}$ & $\begin{array}{c}\text { Balady } \\
3 \\
\end{array}$ & $\begin{array}{c}\text { Balady } \\
4\end{array}$ & $\begin{array}{c}\text { Balady } \\
5\end{array}$ & $\begin{array}{c}\text { Balady } \\
6\end{array}$ & $\begin{array}{c}\text { Balady } \\
7\end{array}$ & $\begin{array}{c}\text { Balady } \\
8 \\
\end{array}$ & Irany & Saudi & $\begin{array}{l}\text { Sobaa } \\
\text { El-Set }\end{array}$ & Oraby & $\begin{array}{l}\text { Red } \\
\text { base }\end{array}$ & $\begin{array}{c}\text { Smooth } \\
\text { green }\end{array}$ & \\
\hline July 5 & 3.33 & 3.33 & 3.33 & 3.33 & 6.67 & 3.33 & 0.00 & 0.00 & 10.00 & 3.33 & 0.00 & 0.00 & 10.00 & 3.33 & $3.57 \mathrm{~F}$ \\
\hline July 12 & 3.33 & 10.00 & 3.33 & 6.67 & 3.33 & 2.00 & 0.00 & 3.33 & 23.33 & 10.00 & 3.33 & 3.33 & 4.67 & 5.00 & $5.83 \mathrm{D}$ \\
\hline July 19 & 3.33 & 3.33 & 6.67 & 3.33 & 0.00 & 3.33 & 0.00 & 3.33 & 3.33 & 10.00 & 10.00 & 3.33 & 3.33 & 4.67 & $4.14 \mathrm{EF}$ \\
\hline July 26 & 3.33 & 2.00 & 3.33 & 5.33 & 3.33 & 2.00 & 0.00 & 13.33 & 4.00 & 10.00 & 2.00 & 3.33 & 6.67 & 6.67 & $4.67 \mathrm{E}$ \\
\hline Aug. 2 & 3.33 & 3.33 & 6.67 & 3.33 & 0.00 & 6.67 & 6.67 & 3.33 & 3.33 & 3.33 & 6.67 & 3.33 & 3.33 & 3.33 & $4.05 \mathrm{EF}$ \\
\hline Aug. 9 & 10.00 & 6.67 & 10.00 & 20.00 & 10.00 & 13.33 & 13.33 & 13.33 & 20.00 & 6.67 & 16.67 & 3.33 & 33.33 & 13.33 & $13.57 \mathrm{~B}$ \\
\hline Aug. 16 & 6.67 & 3.33 & 10.00 & 15.33 & 6.67 & 10.00 & 10.00 & 10.00 & 3.33 & 3.33 & 3.33 & 10.00 & 20.00 & 6.67 & $8.48 \mathrm{C}$ \\
\hline Aug. 23 & 20.00 & 23.33 & 6.67 & 26.67 & 23.33 & 10.00 & 3.33 & 13.33 & 23.33 & 10.00 & 16.67 & 10.67 & 15.00 & 30.00 & $17.02 \mathrm{~A}$ \\
\hline \multirow[t]{2}{*}{ Mean } & 6.67 & 6.92 & 6.25 & 10.50 & 6.67 & 6.33 & 4.17 & 7.50 & 11.33 & 7.08 & 7.33 & 5.42 & 12.04 & 9.13 & \\
\hline & D & D & $\mathrm{DE}$ & $\mathrm{D}$ & D & $\mathrm{DE}$ & $\mathrm{F}$ & D & $A B$ & D & D & $\mathrm{E}$ & A & C & \\
\hline
\end{tabular}

Means followed by the same letter are not significantly different at 0.05 level of probability by Duncan's multiple range test.

@Based on 10 green fruits /replicate. 
Table 4. Mean numbers of (borer + larvae) of Earias insulana on Okra fruits ${ }^{\circledR}$ in Assiut region during 2009 growing season.

\begin{tabular}{|c|c|c|c|c|c|c|c|c|c|c|c|c|c|c|c|}
\hline \multirow{2}{*}{$\begin{array}{c}\text { Inspection } \\
\text { date }\end{array}$} & \multicolumn{14}{|c|}{ Okra varieties } & \multirow[b]{2}{*}{ Mean } \\
\hline & $\begin{array}{c}\text { Balady } \\
1 \\
\end{array}$ & $\begin{array}{c}\text { Balady } \\
2 \\
\end{array}$ & $\begin{array}{c}\text { Balady } \\
3\end{array}$ & $\begin{array}{c}\text { Balady } \\
4 \\
\end{array}$ & $\begin{array}{c}\text { Balady } \\
5\end{array}$ & $\begin{array}{c}\text { Balady } \\
6 \\
\end{array}$ & $\begin{array}{c}\text { Balady } \\
7\end{array}$ & $\begin{array}{c}\text { Balady } \\
8 \\
\end{array}$ & Irany & Saudi & $\begin{array}{l}\text { Sobaa } \\
\text { El-Set }\end{array}$ & Oraby & $\begin{array}{l}\text { Red } \\
\text { base }\end{array}$ & $\begin{array}{l}\text { Smooth } \\
\text { green }\end{array}$ & \\
\hline July 6 & 0.33 & 0.67 & 1.67 & 0.33 & 1.67 & 0.67 & 2.67 & 0.33 & 0.33 & 2.00 & 2.00 & 0.33 & 0.67 & 2.67 & $1.17 \mathrm{C}$ \\
\hline July 13 & 0.33 & 0.33 & 1.33 & 0.33 & 0.10 & 0.33 & 1.67 & 0.10 & 1.00 & 0.10 & 0.33 & 0.10 & 0.67 & 0.33 & $0.50 \mathrm{~F}$ \\
\hline July 20 & 1.00 & 0.33 & 0.10 & 0.10 & 0.67 & 0.33 & 0.67 & 0.33 & 0.10 & 0.10 & 2.00 & 0.10 & 0.33 & 0.67 & $0.49 \mathrm{~F}$ \\
\hline July 27 & 1.33 & 1.33 & 0.67 & 0.67 & 0.67 & 0.67 & 2.00 & 1.00 & 1.33 & 0.33 & 1.33 & 1.00 & 1.00 & 0.10 & $0.96 \mathrm{D}$ \\
\hline Aug. 3 & 1.33 & 0.67 & 0.67 & 0.67 & 0.33 & 0.33 & 0.33 & 0.33 & 0.67 & 0.67 & 0.67 & 1.00 & 0.67 & 1.33 & $0.69 \mathrm{E}$ \\
\hline Aug. 10 & 1.00 & 1.67 & 3.33 & 0.67 & 1.00 & 1.00 & 0.60 & 0.67 & 3.33 & 1.00 & 0.67 & 0.10 & 1.00 & 1.33 & $1.24 \mathrm{C}$ \\
\hline Aug. 17 & 1.67 & 2.67 & 1.00 & 3.00 & 1.33 & 1.33 & 1.67 & 0.67 & 2.00 & 0.33 & 0.33 & 2.67 & 2.00 & 1.00 & $1.55 \mathrm{~B}$ \\
\hline Aug. 24 & 2.67 & 2.67 & 1.33 & 2.00 & 1.67 & 1.67 & 2.00 & 4.33 & 1.67 & 3.00 & 4.33 & 2.67 & 2.00 & 2.00 & $2.43 \mathrm{~A}$ \\
\hline \multirow[t]{2}{*}{ Mean } & 1.21 & 1.29 & 1.26 & 0.97 & 0.93 & 0.79 & 1.45 & 0.97 & 1.30 & 0.94 & 1.46 & 1.00 & 1.04 & 1.18 & \\
\hline & $A B C D$ & $A B$ & $A B C$ & $\mathrm{DE}$ & $\mathrm{DE}$ & $\mathrm{E}$ & A & DE & $A B$ & $\mathrm{DE}$ & $A$ & $\mathrm{CDE}$ & $\mathrm{BCDE}$ & $A B C D$ & \\
\hline
\end{tabular}

Means followed by the same letter are not significantly different at 0.05 level of probability by Duncan's multiple range test.

@Based on 10 green fruits /replicate 
Table 5. Mean numbers of (borer + larvae) of Earias insulana on Okra fruits ${ }^{\circledR}$ in Assiut region during 2010 growing season.

\begin{tabular}{|c|c|c|c|c|c|c|c|c|c|c|c|c|c|c|c|}
\hline \multirow{2}{*}{$\begin{array}{c}\text { Inspection } \\
\text { date }\end{array}$} & \multicolumn{14}{|c|}{ Okra varieties } & \multirow[b]{2}{*}{ Mean } \\
\hline & $\begin{array}{c}\text { Balady } \\
1 \\
\end{array}$ & $\begin{array}{c}\text { Balady } \\
2 \\
\end{array}$ & $\begin{array}{c}\text { Balady } \\
3 \\
\end{array}$ & $\begin{array}{c}\text { Balady } \\
4\end{array}$ & $\begin{array}{c}\text { Balady } \\
5 \\
\end{array}$ & $\begin{array}{c}\text { Balady } \\
6 \\
\end{array}$ & $\begin{array}{c}\text { Balady } \\
7 \\
\end{array}$ & $\begin{array}{c}\text { Balady } \\
8\end{array}$ & Irany & Saudi & $\begin{array}{l}\text { Sobaa } \\
\text { El-Set }\end{array}$ & Oraby & $\begin{array}{l}\text { Red } \\
\text { base }\end{array}$ & $\begin{array}{l}\text { Smooth } \\
\text { green }\end{array}$ & \\
\hline July 5 & 0.67 & 0.00 & 0.00 & 0.00 & 0.00 & 0.33 & 0.67 & 0.67 & 1.33 & 0.33 & 1.00 & 0.67 & 1.33 & 1.33 & $0.60 \mathrm{DE}$ \\
\hline July 12 & 0.33 & 0.33 & 0.00 & 0.33 & 0.33 & 1.33 & 0.67 & 2.00 & 0.33 & 0.10 & 2.67 & 0.33 & 0.10 & 1.33 & $0.73 \mathrm{D}$ \\
\hline July 19 & 0.33 & 0.33 & 0.00 & 1.67 & 0.67 & 0.33 & 0.67 & 0.10 & 0.10 & 0.67 & 0.33 & 1.00 & 0.33 & 0.10 & $0.47 \mathrm{DE}$ \\
\hline July 26 & 0.33 & 1.33 & 0.00 & 0.10 & 0.33 & 0.10 & 0.10 & 1.00 & 0.27 & 0.10 & 0.33 & 0.20 & 1.00 & 1.00 & $0.44 \mathrm{E}$ \\
\hline Aug. 2 & 0.67 & 1.00 & 0.33 & 0.67 & 0.33 & 0.67 & 0.33 & 0.33 & 0.10 & 1.67 & 0.67 & 0.67 & 0.33 & 0.37 & $0.58 \mathrm{DE}$ \\
\hline Aug. 9 & 1.67 & 1.67 & 1.33 & 3.00 & 0.67 & 1.33 & 0.33 & 0.67 & 1.33 & 1.67 & 3.33 & 1.33 & 3.67 & 1.67 & $1.90 \mathrm{~B}$ \\
\hline Aug. 16 & 0.67 & 1.00 & 1.67 & 0.67 & 1.00 & 0.67 & 1.33 & 0.67 & 1.33 & 1.00 & 0.67 & 1.33 & 2.00 & 1.00 & $1.07 \mathrm{C}$ \\
\hline Aug. 23 & 2.67 & 1.33 & 0.33 & 2.00 & 3.33 & 3.00 & 3.33 & 1.00 & 3.00 & 1.33 & 2.67 & 0.67 & 2.00 & 4.00 & $2.19 \mathrm{~A}$ \\
\hline \multirow[t]{2}{*}{ Mean } & 0.92 & 0.88 & 0.46 & 1.05 & 0.83 & 0.97 & 1.30 & 0.80 & 0.98 & 0.86 & 1.46 & 0.78 & 1.35 & 1.35 & \\
\hline & $\mathrm{D}$ & D & $\mathrm{E}$ & $\mathrm{BCD}$ & $D$ & $\mathrm{CD}$ & $\mathrm{ABC}$ & $\mathrm{D}$ & $\mathrm{CD}$ & $D$ & A & $\mathrm{DE}$ & $A B$ & $A B$ & \\
\hline
\end{tabular}

Means followed by the same letter are not significantly different at 0.05 level of probability by Duncan's multiple range test.

@Based on 10 green fruits /replicate. 


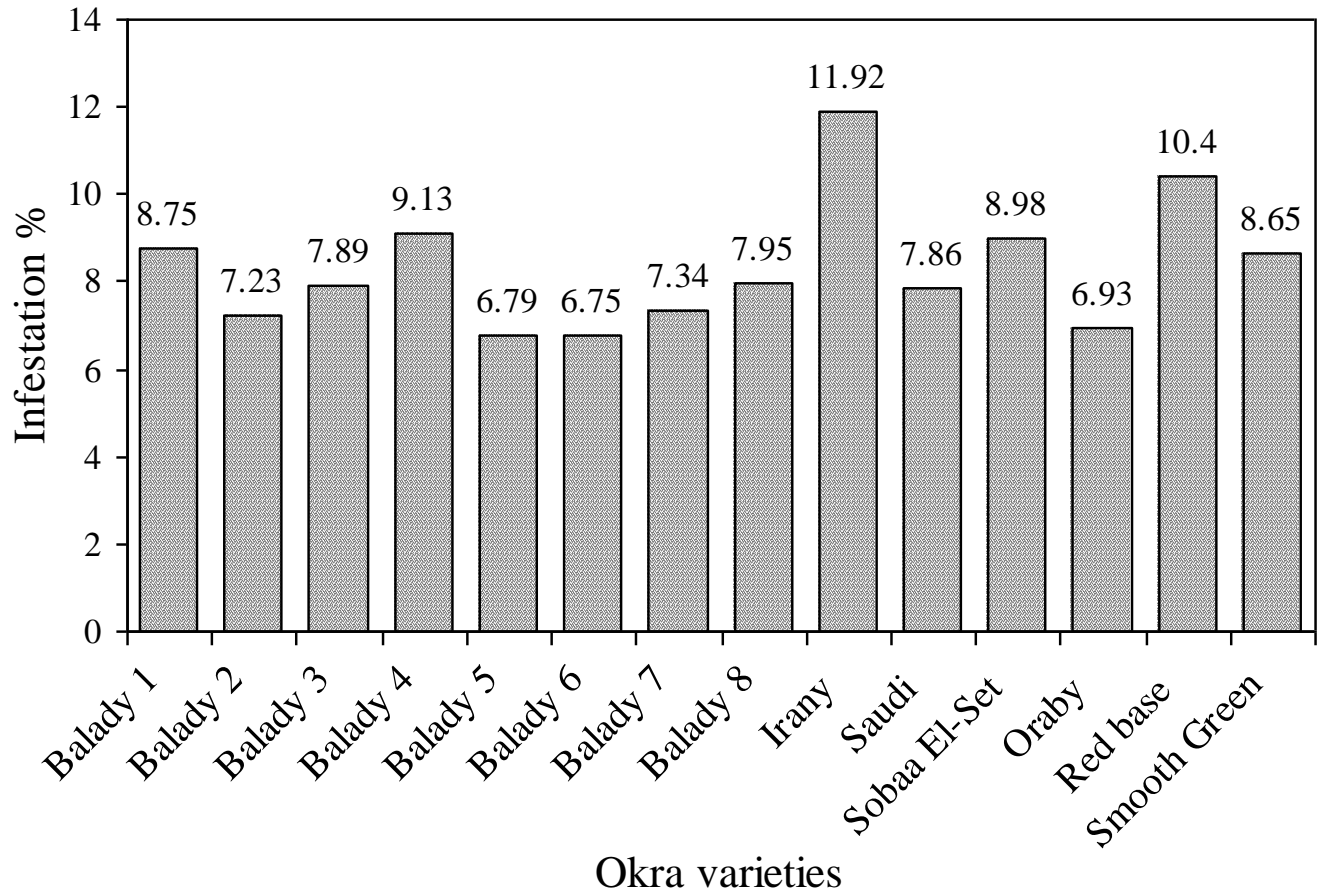

Figure 1. Mean infestation percentage of Earias insulana on Okra fruits in Assiut region during 2009 and 2010 growing season. 
Table 6. Resistance status of Okra varieties against Earias insulana infestation at Assiut governorate during 2009 and 2010 growing seasons ${ }^{@}$.

\begin{tabular}{|c|c|c|c|c|}
\hline \multirow{2}{*}{ Okra varieties } & \multicolumn{3}{|c|}{ Mean number of (Bores + larvae) } & \multirow{2}{*}{$\begin{array}{c}\text { Resistance } \\
\text { status }\end{array}$} \\
\hline & 2009 & 2010 & Mean \pm SD & \\
\hline Balady 1 & 1.21 & 0.92 & $\begin{array}{c}1.07 \mathrm{BC} \pm \\
0.20\end{array}$ & $\mathrm{~S}$ \\
\hline Balady 2 & 1.29 & 0.88 & $\begin{array}{c}1.09 \mathrm{BC} \pm \\
0.29\end{array}$ & $S$ \\
\hline Balady 3 & 1.26 & 0.46 & $\begin{array}{c}0.86 \mathrm{D} \pm \\
0.14\end{array}$ & $H R$ \\
\hline Balady 4 & 0.97 & 1.05 & $\begin{array}{c}1.01 \mathrm{C} \pm \\
0.06\end{array}$ & LR \\
\hline Balady 5 & 0.93 & 0.83 & $\begin{array}{c}0.88 \mathrm{D} \pm \\
0.07\end{array}$ & $\mathrm{HR}$ \\
\hline Balady 6 & 0.79 & 0.97 & $\begin{array}{c}0.88 \mathrm{D} \pm \\
0.07\end{array}$ & $H R$ \\
\hline Balady 7 & 1.45 & 1.30 & $\begin{array}{c}1.38 \mathrm{~A} \pm \\
0.11\end{array}$ & HS \\
\hline Balady 8 & 0.97 & 0.80 & $\begin{array}{c}0.89 \mathrm{CD} \pm \\
0.12 \\
\end{array}$ & MR \\
\hline Irany & 1.30 & 0.98 & $\begin{array}{c}1.14 \mathrm{BC} \pm \\
0.23\end{array}$ & S \\
\hline Saudi & 0.94 & 0.86 & $\begin{array}{c}0.90 \mathrm{CD} \pm \\
0.23\end{array}$ & MR \\
\hline Sobaa El-Set & 1.46 & 1.46 & $\begin{array}{c}1.46 \mathrm{~A} \pm \\
0.71\end{array}$ & HS \\
\hline Oraby & 1.00 & 0.78 & $\begin{array}{c}0.89 \mathrm{CD} \pm \\
0.16 \\
\end{array}$ & MR \\
\hline Red base & 1.04 & 1.35 & $\begin{array}{c}1.20 \mathrm{~B} \pm \\
0.22\end{array}$ & $\mathrm{~S}$ \\
\hline Smooth green & 1.18 & 1.35 & $\begin{array}{c}1.27 \mathrm{~B} \pm \\
0.12\end{array}$ & HS \\
\hline Mean \pm SD & $1.13 \pm 0.21$ & $1.00 \pm 0.28$ & $1.07 \pm 0.09$ & \\
\hline
\end{tabular}

Means followed by the same letter are not significantly different at 0.05 level of probability by Duncan's multiple range test.

@Based on 10 green fruits /replicate. 
Table 7. Correlation between Earias insulana infestation and some physical and chemical Okra characters.

\begin{tabular}{|c|c|c|c|c|c|c|}
\hline Okra varieties & $\begin{array}{c}\text { Hairs } \\
\mu\left(10^{-6} \mathrm{~cm}\right)\end{array}$ & $\begin{array}{c}\mathrm{K} \\
\mathrm{Mg} / \mathrm{g} \\
\text { Dry wt. }\end{array}$ & $\begin{array}{c}\mathrm{Ca} \\
\mathrm{Mg} / \mathrm{g} \\
\text { Dry wt. }\end{array}$ & $\begin{array}{c}\mathrm{Mg} \\
\mathrm{Mg} / \mathrm{g} \\
\text { Dry wt. }\end{array}$ & $\begin{array}{c}\text { Prot. } \\
\mathrm{Mg} / \mathrm{g} \\
\text { Dry wt. }\end{array}$ & $\begin{array}{l}\text { Sugar } \\
\mathrm{Mg} / \mathrm{g} \\
\text { Dry wt. }\end{array}$ \\
\hline Balady 1 & $\begin{array}{c}836.7 b \\
(0.04)\end{array}$ & $\begin{array}{l}7.843 c \\
(-0.094)\end{array}$ & $\begin{array}{c}6.333 \mathrm{de} \\
(-0.069)\end{array}$ & $\begin{array}{l}2.033 \mathrm{e} \\
(0.051)\end{array}$ & $\begin{array}{c}57.61 \text { def } \\
(-0.047)\end{array}$ & $\begin{array}{r}20.33 A \\
(-0.046)\end{array}$ \\
\hline Balady 2 & $\begin{array}{l}830.0 \mathrm{~b} \\
(0.049)\end{array}$ & $\begin{array}{c}9.657 a b c \\
(-0.04)\end{array}$ & $\begin{array}{c}7.000 \text { cde } \\
(-0.03)\end{array}$ & $\begin{array}{l}2.033 \mathrm{e} \\
(0.003)\end{array}$ & $\begin{array}{l}49.32 \mathrm{fg} \\
(-0.039)\end{array}$ & $\begin{array}{c}8.74 \mathrm{fg} \\
(-0.009)\end{array}$ \\
\hline Balady 3 & $\begin{array}{l}736.7 \text { b } \\
(0.002)\end{array}$ & $\begin{array}{c}8.377 \text { bc } \\
(-0.01)\end{array}$ & $\begin{array}{c}8.333 a b c \\
(0.006)\end{array}$ & $\begin{array}{c}4.067 \mathrm{bcd} \\
(0.006)\end{array}$ & $\begin{array}{l}69.78 \mathrm{~cd} \\
(-0.013)\end{array}$ & $\begin{array}{l}11.83 \mathrm{de} \\
(-0.004)\end{array}$ \\
\hline Balady 4 & $\begin{array}{l}750.0 \mathrm{~b} \\
(0.028)\end{array}$ & $\begin{array}{l}9.250 \text { bc } \\
(-0.001)\end{array}$ & $\begin{array}{c}9.000 \mathrm{ab} \\
(0.028)\end{array}$ & $\begin{array}{c}3.253 \text { cde } \\
(0.216)\end{array}$ & $\begin{array}{l}85.41 b \\
(0.032)\end{array}$ & $\begin{array}{l}16.17 b \\
(-0.030)\end{array}$ \\
\hline Balady 5 & $\begin{array}{l}710.0 b \\
(-0.024)\end{array}$ & $\begin{array}{c}8.677 \text { bc } \\
(0.035)\end{array}$ & $\begin{array}{c}8.333 a b c \\
(0.042)\end{array}$ & $\begin{array}{l}2.033 \mathrm{e} \\
(-0.045)\end{array}$ & $\begin{array}{c}60.28 \text { def } \\
(0.010) \\
\end{array}$ & $\begin{array}{l}8.04 \mathrm{~g} \\
(0.009) \\
\end{array}$ \\
\hline Balady 6 & $\begin{array}{l}570.0 \mathrm{~b} \\
(-0.018)\end{array}$ & $\begin{array}{l}11.50 \mathrm{a} \\
(0.014)\end{array}$ & $\begin{array}{l}5.667 \text { e } \\
(-0.002)\end{array}$ & $\begin{array}{c}2.237 \mathrm{de} \\
(0.002)\end{array}$ & $\begin{array}{c}60.69 \text { def } \\
(-0.008)\end{array}$ & $\begin{array}{c}13.32 \text { cde } \\
(0.013)\end{array}$ \\
\hline Balady 7 & $\begin{array}{c}1183.3 \mathrm{a} \\
(0.01)\end{array}$ & $\begin{array}{l}8.532 b c \\
(-0.009)\end{array}$ & $\begin{array}{c}7.667 \mathrm{bcd} \\
(0.018)\end{array}$ & $\begin{array}{c}3.457 \text { cde } \\
(-0.006)\end{array}$ & $\begin{array}{l}77.66 \text { bc } \\
(-0.016)\end{array}$ & $\begin{array}{l}9.08 \mathrm{fg} \\
(0.013)\end{array}$ \\
\hline Balady 8 & $\begin{array}{c}1253.3 \mathrm{a} \\
(-0.007)\end{array}$ & $\begin{array}{c}10.42 a b \\
(0.002)\end{array}$ & $\begin{array}{c}7.000 \text { cde } \\
(-0.022)\end{array}$ & $\begin{array}{c}3.357 \text { cde } \\
(0.008)\end{array}$ & $\begin{array}{l}40.63 \mathrm{~g} \\
(0.004)\end{array}$ & $\begin{array}{c}8.80 \mathrm{fg} \\
(-0.018)\end{array}$ \\
\hline Irany & $\begin{array}{l}746.7 \mathrm{~b} \\
(0.034)\end{array}$ & $\begin{array}{l}8.050 c \\
(-0.017)\end{array}$ & $\begin{array}{c}6.667 \text { cde } \\
(0.021)\end{array}$ & $\begin{array}{l}4.780 b c \\
(-0.039)\end{array}$ & $\begin{array}{l}50.93 \mathrm{fg} \\
(-0.038)\end{array}$ & $\begin{array}{c}13.50 \mathrm{~cd} \\
(0.039)\end{array}$ \\
\hline Saudi & $\begin{array}{l}600.0 \mathrm{~b} \\
(0.039)\end{array}$ & $\begin{array}{c}8.760 \text { bc } \\
(0.019)\end{array}$ & $\begin{array}{c}8.333 a b c \\
(-0.056)\end{array}$ & $\begin{array}{c}2.440 \text { de } \\
(0.018)\end{array}$ & $\begin{array}{c}67.23 \text { cde } \\
(-0.002)\end{array}$ & $\begin{array}{l}15.09 b c \\
(-0.024)\end{array}$ \\
\hline Sobaa El-Set & $\begin{array}{c}1333.3 \mathrm{a} \\
(0.022)\end{array}$ & $\begin{array}{c}8.620 \text { bc } \\
(0.088)\end{array}$ & $\begin{array}{c}9.000 \mathrm{ab} \\
(0.025)\end{array}$ & $\begin{array}{c}3.050 \text { cde } \\
(-0.075)\end{array}$ & $\begin{array}{c}53.60 \mathrm{efg} \\
(0.078)\end{array}$ & $\begin{array}{c}11.06 \text { ef } \\
(0.069)\end{array}$ \\
\hline Oraby & $\begin{array}{c}1253.3 \mathrm{a} \\
(0.057)\end{array}$ & $\begin{array}{c}9.487 a b c \\
(-0.057)\end{array}$ & $\begin{array}{c}7.333 \text { cde } \\
(-0.036)\end{array}$ & $\begin{array}{c}3.660 \text { cde } \\
(-0.031)\end{array}$ & $\begin{array}{r}47.72 \mathrm{fg} \\
(-0.057)\end{array}$ & $\begin{array}{c}9.30 \mathrm{fg} \\
(-0.008)\end{array}$ \\
\hline Red Base & $\begin{array}{l}736.7 \text { b } \\
(0.025)\end{array}$ & $\begin{array}{c}9.600 a b c \\
(-0.062)\end{array}$ & $\begin{array}{l}10.00 \mathrm{a} \\
(0.043)\end{array}$ & $\begin{array}{r}6.710 a \\
(-0.063) \\
\end{array}$ & $\begin{array}{l}110.1 \mathrm{a} \\
(0.008) \\
\end{array}$ & $\begin{array}{l}17.11 \mathrm{~b} \\
(0.047)\end{array}$ \\
\hline Smooth green & $\begin{array}{l}633.3 b \\
(0.008)\end{array}$ & $\begin{array}{c}8.633 \text { bc } \\
(0.023)\end{array}$ & $\begin{array}{c}9.000 \mathrm{ab} \\
(0.045)\end{array}$ & $\begin{array}{c}5.693 a b \\
(-0.047)\end{array}$ & $\begin{array}{l}100.1 \mathrm{a} \\
(0.004)\end{array}$ & $\begin{array}{l}17.25 b \\
(-0.044)\end{array}$ \\
\hline F value & $9.45 * *$ & $2.28 *$ & $4.33 * *$ & $6.69 * *$ & $2.26 * *$ & $26.33 * *$ \\
\hline
\end{tabular}

Means followed by the same letter are not significantly different at 0.05 level of probability by Duncan's multiple range tests.

( ) Numbers between parenthesis refer to correlation coefficient values. 


\section{الحساسية النسبية لبعض أصناف الباميا لدودة اللوز الثوكية}

\section{Earias insulana (Boisd.)}

محمد عبد الرحمن محمد عمرو، جمال حسين عبد الرحيم وياسر محمد عبد القوى عبد الجليل1

$$
\text { 2. } 1 \text {. معهد بحوث وقابة النبات - مركز البحوث الزراعية - الدقي - الجبية . }
$$

تم تقدير درجات الإصـابة بدودة اللوز الشوكية Earias insulana (Boisd. لأربعة عشر صنفاً

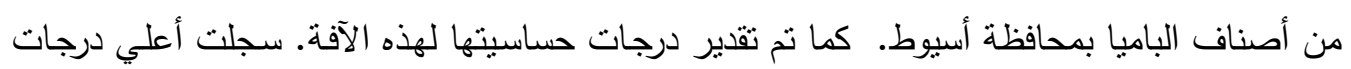

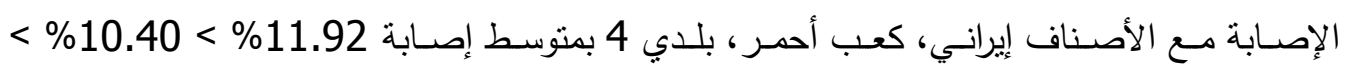

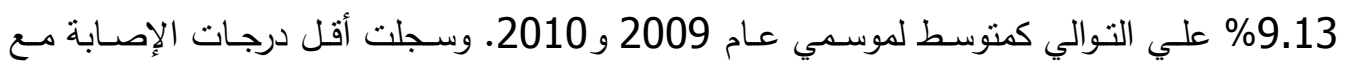

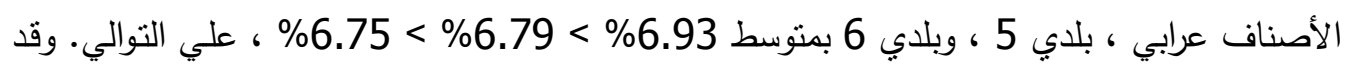

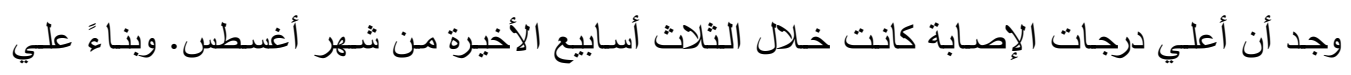

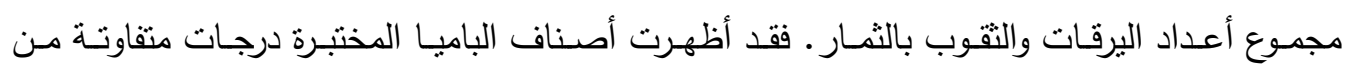

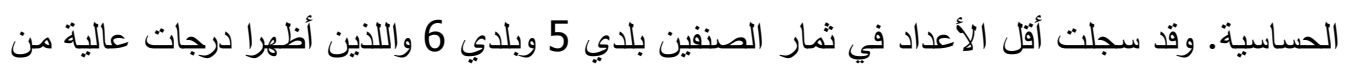

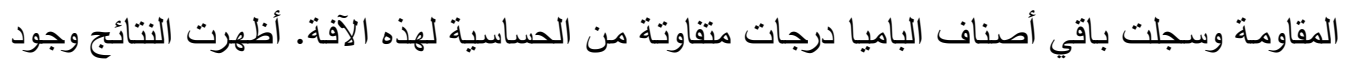

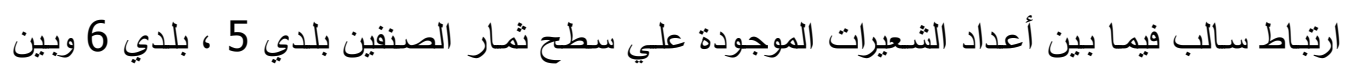

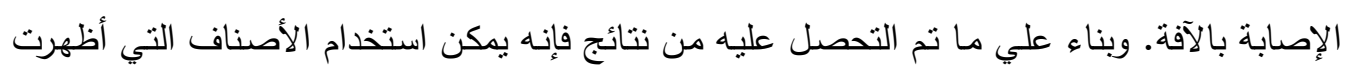
نوع من المقاومة للآفة في برامج تربية متقدمة لإنتاج أصناف جديدة مقاومة للآفة. 